działania, a na pewno wielu osobom pomogły w działalności zawodowej, czego przykładem mogą być nauczyciele języka angielskiego rozsiani po bloku wschodnim.

Publikacja A. Reischa jest udaną monografią, lecz z perspektywy polskiej historiografii nie do końca satysfakcjonującą. Jak już wspomniano, przede wszystkim pomija niezwykle ciekawy okres po szczycie KBWE oraz czasy stanu wojennego. Nie dowiemy się także, jaki wpływ na program miał drugi obieg bezdebitowych wydawnictw oraz „karnawał” Solidarności. Warto jednak w tym miejscu zaznaczyć, że czytelnik otrzymuje pracę historyczną o programie dystrybucji książek do Europy Środkowej, realizowanym w momencie, w którym Polska odgrywała w nim najważniejszą rolę. Nieznany front zimnej wojny to w zamierzeniu książka o książkach, jednak właśnie tego elementu brakuje w tej publikacji. Czytelnik otrzymuje wiele danych i liczb, jednak o roli książek i ideach, jakie niosły, niewiele się dowie. Po lekturze dzieła A. Reischa będziemy znali wiele tytułów i gatunków, jednak nie będziemy sobie zdawali sprawy, dlaczego takie, a nie inne książki były postrzegane przez system komunistyczny jako zagrożenie.

Alfred Reisch pod koniec swego życia postawił sobie za cel przekazanie, przedstawienie historii tajnego programu dystrybucji książek do bloku wschodniego, co w dużej mierze mu się udało. Warto zauważyć, że pisał swoje dzieło już w trakcie zaawansowanej choroby i zmarł ledwie kilka tygodni po publikacji angielskiego wydania Hot Books in Cold War, więc można je bez wątpienia uznać za jego opus magnum. Możliwe, że gdyby zrealizował swoje zamierzenia i napisał dodatkowe dwa tomy, zawierające historię kolportażu książek do krajów bałtyckich ${ }^{24}$ oraz zbiór relacji osób zaangażowanych w program ${ }^{25}$, książka Nieznany front zimnej wojny mogłaby być postrzegana w bardziej komplementarny sposób. Wypada jednak się zgodzić z recenzentami, którzy już pochylali się nad angielskojęzyczną wersją książki, i przyznać, że praca A. Reischa, mimo braków i pewnych uchybień, na pewno jest lekturą wartą przeczytania, a jej publikacja stanowi ważny punkt, po którym branie pod uwagę programu dystrybucji książek za żelazną kurtynę staje się przymusem.

\title{
Wojciech Bednarski
}

${ }^{24}$ Wystąpienie A. Reischa na konferencji „Art and Political Reality”, Kumu Art Museum w Tallinie, 26-27 października $2012 \mathrm{r}$.

${ }^{25}$ Wypowiedź J. Tishlera podczas audycji Naukowy zawrót głowy prowadzonej przez K. Jankowską, Polskie Radio Program I, 11.05.2015 r.

O miejsce książki w historii sztuki. Red. Agnieszka Gronek, Kraków: Collegium Columbinum 2015, 523 s., XXXIV, ISBN 978-83-7624-132-6

DOI: $10.19195 / 0080-3626.60 .19$

Mimo niebagatelnej roli, jaką książka odegrała w dziejach sztuki, obecność refleksji nad nią w polskich badaniach historyczno-artystycznych wciąż jest daleka od kompletności, albowiem zdecydowanie częściej niźli historycy sztuki badaniami nad książką zajmują się specjaliści innych dziedzin, zwłaszcza bibliolodzy i filolodzy, którzy jednakże 
czynią to z perspektywy właściwej ich specjalności, a to oznacza, że o zagadnieniach przynależnych historii sztuki jedynie wzmiankują lub całkowicie je pomijają. Co ciekawe, także w badaniach samych historyków sztuki książka zajmuje często miejsce dalekie od należnego. Refleksje nad stroną estetyczną manuskryptów i druków podejmowane są najczęściej na marginesie rozważań poświęconych innym zagadnieniom, tylko sporadycznie stając się zasadniczym przedmiotem analiz. $Z$ niezgody na taki właśnie stan rzeczy zrodził się pomysł zorganizowania w grudniu 2012 roku konferencji naukowej pod hasłem: „O miejsce książki w historii sztuki”1, która za swój cel miała „przywrócić pamięć o książce jako dziele sztuki, przedmiocie pięknym i cennym, podkreślić jej wiodącą rolę $\mathrm{w}$ inicjowaniu i propagowaniu zmian $\mathrm{w}$ sztukach plastycznych poprzez rozpowszechnianie nowych motywów estetycznych i ikonograficznych, pojęć, tematów i wyobrażeń" (Wstęp, s. 9). Pokłosiem owego naukowego spotkania stał się zbiór artykułów wydany pod redakcją Agnieszki Gronek oraz tym samym tytułem, który stanowi przedmiot niniejszej recenzji.

A zbiór to cenny i ze wszech miar godny uwagi, gdyż książka jest w nim rzeczywiście główną bohaterką wszystkich tekstów, tych zaś jest aż trzydzieści sześć. Jak to jednak w wypadku publikacji pokonferencyjnych bywa, poszczególne artykuły są bardzo różnorodne, i to zarówno pod względem sposobu podejścia do zasadniczego tematu, stopnia szczegółowości, jak i ciężaru podejmowanych zagadnień. Zapewne ze względu na rozpiętość poruszanych w nich problemów teksty nie zostały pogrupowane w mniejsze działy, lecz ułożone w porządku wyznaczonym z grubsza chronologią analizowanych dzieł i zjawisk artystycznych.

Tom otwiera zatem artykuł Katarzyny Płonki-Bałus (Średniowieczna książka iluminowana jako przedmiot badań historii sztuki, s. 11-21), zawierający obszerne omówienie dotychczasowego stanu badań nad niderlandzkim malarstwem książkowym XV stulecia, z jednoczesnym wskazaniem kierunków, w jakich mogą podążać dalsze analizy dzieł powstałych w tym jakże płodnym i ciekawym kręgu artystycznym.

Problemowi obecności obrazów we wschodniej, a konkretnie bizantyńskiej książce wieków średnich uwagę poświęca z kolei Małgorzata Smorąg Różycka (Obrazy w bizantyńskich książach: słowne, malowane, myślowe, s. 23-41), swoje rozważania opierając głównie na iluminacjach z datowanego na IX wiek Psałterza Chłudowa.

Swoistą minimonografię jednego obiektu — piętnastowiecznych Godzinek powstałych w kręgu francuskim - przedstawia natomiast Magdalena Lanuszka (Rękopis Godzinek MS Czart. 3467 - wyniki dalszych badań, s. 43-56), uaktualniając w swym tekście wnioski i hipotezy zaprezentowane już parę lat wcześniej². Tych samych czasów, lecz innego środowiska artystycznego dotyczy z kolei tekst Wizerunki kondotierów w kodeksach włoskich w XV wieku (s. 57-65), którego autorka — Agnieszka Smołucha-Sładkowska — porusza między innymi problem specyfiki iluminowanych wyobrażeń kondotierów,

${ }^{1}$ Organizatorami konferencji byli: Krakowski Oddział Stowarzyszenia Historyków Sztuki przy współpracy Muzeum Narodowego w Krakowie, tamtejszej Akademii Sztuk Pięknych oraz Biblioteki Jagiellońskiej.

2 Magdalena LANUSZKA, Piętnastowieczny rękopis Godzinek w krakowskiej Bibliotece Książąt Czartoryskich, Modus. Prace z Historii Sztuki (6) 2006, s. 83-98. 
w tym przede wszystkim ich relacji do rzeczywistego wyglądu portretowanych postaci oraz ich bardziej reprezentacyjnych i oficjalnych wizerunków (np. rzeźbionych).

Kolejne teksty wprowadzają już w krąg książki drukowanej i zagadnień związanych z jej zdobnictwem. Artykuł Iwony Długopolskiej traktuje o najbardziej charakterystycznych cechach szaty typograficznej inkunabułów (Druk jako sztuka - szata typograficzna inkunabułów, s. 67-74) ${ }^{3}$, Joanna A. Tomicka zaś (,,Liber pulcher”. O przykładach paryskiej i lyońskiej „typografii wytwornej” XVI w., s. 83-94) kieruje uwagę na efekty pracy paryskiej oficyny Thielmana Kervera oraz lyońskiego warsztatu Jeana de Tournes i Guijome’a Rovije, wskazując je jako przykłady typografii wytwornej ${ }^{4}$. Problem pięknej książki porusza również Klaudia Socha, której tekst ( $N a$ czym polega piękno ksiązik? Estetyczne podstawy projektu typograficznego, s. 379-390) dotyka niezwykle ważkiego problemu estetyki projektów typograficznych. Odwołując się między innymi do Witruwiańskich Dziesięciu ksiag o architekturze oraz ustaleń Pitagorasa i Arystotelesa, autorka umiejętnie dowodzi, że kategorie estetyczne sięgające swą genezą antyku są uniwersalne i obowiązują w projektowaniu typograficznym i graficznym różnych epok, w tym współcześnie.

Cenne dopełnienie obrazu książki dawnej przynosi artykuł Agnieszki Perzanowskiej (Orientalne inspiracje w introligatorstwie krakowskim XVI wieku, s. 75-82) — notabene w całym tomie jedyny z zakresu tegumentologii — poświęcony introligatorstwu krakowskiemu XVI stulecia i obecności w nim wyraźnych wpływów sztuki orientalnej.

Niezwykle ciekawe i istotne zagadnienie inspirującej roli grafiki książkowej w przekazywaniu wzorów ikonograficznych i kompozycyjnych poruszają z kolei teksty Janiny Dzik (Ryciny z „Menologium” (1698) Fortunata Huebera i ich recepcja $w$ malarstwie lwowskim XVIII w., s. 95-108) i Agnieszki Gronek (Niderlandzkie źródła obrazowe kijowskiego wzornika - Triodonu Kwietnego (Kijów 1631), s. 139-146). Podobny problem sygnalizuje artykuł Aleksandry Sulikowskiej (Księgi i ikony a problem wzorów ikonograficznych: zachodnia Ruś i Mołdawia w XV-XVI wieku (uwagi wstępne), s. 125-138).

Wiele cennych wniosków do badań nad ilustracją książkową wnosi także tekst Małgorzaty Pokorskiej-Primus (Od ,Spektaklu Cnót, Sztuk i Nauk” do „Monument du

3 Szkoda jedynie, że artykuł ten jest, niestety, mało oryginalny i poza wiedzą o tym, co kryją zasoby Muzeum Narodowego w Krakowie, nie wnosi nic nowego, a nadto, opierając się na opracowaniach najbardziej rudymentarnych z możliwych, wskazuje na słabą orientację autorki w literaturze przedmiotu. Mimo istnienia całkiem sporej liczby (również polskojęzycznych) artykułów i opracowań poświęconych sztuce typograficznej inkunabułów, autorka tekstu przywołała tylko prace: Heleny SZWEJKOWSKIEJ, Ksiażka drukowana XV-XVIII w., Wrocław-Warszawa: Zakład Narod. im. Ossolińskich 1961 i Encyklopedię wiedzy o książce. Praca zbiorowa pod red. Aleksandra Birkenmajera, Bronisława Kocowskiego i Jana Trzynadlowskiego, Wrocław-Warszawa-Kraków: Zakład Narod. im. Ossolińskich 1971.

${ }^{4}$ Niestety, w pracy tej dostrzec można kilka nieco zdumiewających omyłek, by wspomnieć jedynie użycie terminu modus modernus (s. 85) w odniesieniu do kompozycji stronicy Godzinek, w których — z racji charakteru i wielkości owej książeczki — tego schematu nie stosowano, czy przyjęciu dla kroju pisma antykwowego określenia italika (s. 85), które wszak zarezerwowane jest dla pism pochyłych. Zaskakująca jest również swoista niefrasobliwość w konstruowaniu podpisów pod ilustracjami, w wyniku której karta pochodząca z kalendarza z Godzinek anonimowego autorstwa staje się kartą z dzieła Thielmana Kervera zatytułowanego Modlitewnik (Horae), (s. 92, il. 1). 
costume”. O francuskiej grafice książkowej XVIII wieku, s. 109-124), zawierający syntetyczną, lecz bardzo wnikliwą charakterystykę francuskiej grafiki ilustracyjnej XVIII stulecia, dopełnioną opisem najlepszych jej przykładów i bardzo bogatą literaturą przedmiotu. Z kolei Agata Miatkowska-Gołdyn skupia się w swoim studium na problemie wpływu norweskich edycji baśni autorstwa Pera Christena Asbjørnsena i Jørgena Moe oraz ich wyposażenia ilustracyjnego na kształtowanie się sztuki neoromatycznej w Norwegii (Baśniowa rewolucja. Wpływ baśni ludowych Asbjørnsena i Moe na neromantyzm w Norwegii, s. 291-304), szczególną uwagę poświęcając twórczości jednego z najpopularniejszych rysowników norweskich tamtych czasów - Theodora Kittelsena. Przedmiotem analizy Ewy Rutkiewicz jest natomiast ilustracja polskiej książki dla dzieci przełomu XIX i XX wieku (s. 305-322).

Wśród artykułów zgromadzonych w recenzowanym tomie nie brakuje również prac poświęconych wyposażeniu graficznemu jednego dzieła lub dzieł jednego autora. Mianowicie Anna Grochala skupia swoją uwagę na plastycznym ,akompaniamencie” Śpiewów historycznych Juliana Ursyna Niemcewicza, opisując wystrój ilustracyjny dziewiętnastowiecznych wydań tego utworu i jego oddziaływanie między innymi na malarstwo historyczne (,,Śpiewy historyczne” Juliana Ursyna Niemcewicza i ich rola w kształtowaniu wizji dziejów narodowych Polaków, s. 257-276), a Piotr Rosiński opisuje ilustracje i ilustratorów dzieł Stefana Żeromskiego (s. 277-290).

Nieco odmienne typy publikacji są z kolei przedmiotem analiz Kamilli Pijanowskiej, która koncentruje się na sztychach składających się na wydany w 1884 roku Album malarzy polskich zawierający reprodukcje dzieł artystów tworzących tak zwaną szkołę polską (Wytworność i taniość. O „Albumie malarzy polskich w sztychach z tekstem objaśniającym prof. Henryka Struvego”, s. 323-336) oraz Krystyny Kulig-Janarek przedstawiającej stan badań nad Xiega Batwochwalcza, czyli teką prac graficznych autorstwa Brunona Schulza (s. 421-436).

Zgoła odmienne zagadnienie podejmuje Alicja Z. Nowak (Materiaty niekonieczne w księgach liturgicznych: objaśnienia dla kapłanów na przykładzie ,,antimensionu”, s. 147-174), skupiając uwagę na problemie materiałów dopełniających zasadnicze teksty cerkiewnych ksiąg liturgicznych i objaśniając go na przykładzie zapisów dotyczących antimensionu oraz ilitonu. Kręgu ksiąg cerkiewnych dotyczy również artykuł Waldemara Delugi ( $O$ drukach lwowskich z przełomu XVII i XVIII wieku ilustrowanych drzeworytami Nikodema Zubrzyckiego, s. 175-184), zawierający omówienie twórczości graficznej jednego z bardziej znaczących artystów cerkiewnych przełomu wieków XVII i XVIII, pracującego między innymi dla drukarni stauropigialnej we Lwowie.

Tekst Piotra Jaworskiego (Początki europejskiej literatury numizmatycznej i jej rola w upowszechnianiu antycznej ikonografii monetarnej w Polsce XVI wieku, s. 185-198) przybliża natomiast kwestię wpływu, jakie dzieła numizmatyczne wywarły na antyczną ikonografię monetarną, która znajduje swoje odbicie między innymi w wyobrażeniach władców zdobiących bardzo popularne w szesnastowiecznej Polsce kroniki i zbiory żywotów. Tematykę numizmatyczną porusza też Bartłomiej Czarski (Antyczne motywy numizmatyczne w emblematach Andreasa Alciatusa w kontekście źródet literackich, s. 199212), koncentrujący się na zagadnieniu wyszukiwania motywów znanych z antycznych monet w alciatusowej Emblematum libellus. 
W tomie nie zabrakło tekstów poświęconych współczesnej książce, jej wystrojowi, specyfice, a także wybitnym postaciom z nią związanym. Sylwetkę Witolda Chomicza - wybitnego typografa, ilustratora i bibliofila — przybliża Magdalena Laskowska (s. 347-362) — kurator wystawy zorganizowanej w Muzeum Narodowym w Krakowie i autorka towarzyszącego imprezie katalogu ${ }^{5}$, Janusz Antos przedstawia zaś twórczość Janiny Kraupe — autorki licznych haiku oraz Księgi Kontrastów i Księgi Tajemnic (s. 391-402).

Zagadnienia związane z książką wychodzącą już często poza tradycyjną formę stanowią natomiast przedmiot zainteresowania Piotra Hordyńskigo, który stara się ustalić: Czy istnieje książka artystyczna? (s. 363-378), próbując przede wszystkim doprecyzować to, co zwykło się tym pojęciem określać, a co — wobec rozwoju różnych form książki artystycznej oraz licznych wersji obcojęzycznych tego terminu (livre d'artiste, Malerbuch, artist's book, bookworks) — jest coraz mniej jasne. W tym samym kręgu tematycznym pozostaje też Magdalena Czubińska, która prezentuje książki artystyczne, książki-obiekty i książki-autorskie projektu Aliny Kalczyńskiej (s. 403-420) oraz Agnieszka Jankowska-Marzec przybliżająca sylwetkę i twórczość Bogusława Bachorczyka - malarza, fotografa, autora książek artystycznych, dla którego głównym źródłem inspiracji jest jego własna biografia (s. 437-450). Z kolei Bernadeta Stano opisuje instalację typograficzną autorstwa Ewy Sataleckiej, przy okazji stawiając pytania o granice książki (s. 451-466).

Poza krąg dotychczas prezentowanych zagadnień wykracza tekst Janusza L. Dobesza poświęcony miejscu książki w krajobrazie kultury Polski powojennej (s. 467-482) i sygnalizujący wiele problemów, które wynikają z takiego ujęcia. Ciekawą perspektywę badawczą proponuje również Elżbieta Laskowska, która koncentruje się na książkach, jej twórcach i odbiorcach widzianych oczyma współczesnych polskich karykaturzystów, między innymi Henryka Tomaszewskiego, Eryka Lipińskiego i Karola Ferstera ps. „Charlie" (s. 483-496).

W tomie znalazły się też teksty przybliżające zbiory różnych bibliotek oraz muzeów. Swoje badania nad szesnasto- oraz siedemnastowiecznymi drukami o tematyce architektonicznej, które znajdują się w zasobach Biblioteki Gdańskiej Polskiej Akademii Nauk, zreferował Franciszek Skibiński (Książka i grafika o tematyce architektonicznej w nowożytnym Gdańsku. Wprowadzenie i nowe ustalenia, s. 213-226), a Aneta Czarnecka przybliżyła wykonane przez Hansa Thomę na początku XX wieku projekty „Wiecznego kalendarza w obrazach", przechowywane w Muzeum Narodowym w Warszawie (s. 227-242). Do zbiorów tej samej instytucji sięgnęła również Ewa Frąckowiak, która na podstawie znajdujących się tam prac Maxa Slevogta oraz Emila Rudolfa Weissa przedstawiła zagadnienie toczącej się u schyłku XIX i na początku XX stulecia walki o piękną książkę (,,Buchkunstbewegung”. Batalia o piękna książke w Niemczech około 1900 roku na wybranych przykładach ze zbiorów Gabinetu Rycin i Rysunków Muzeum Narodowego $w$ Warszawie, s. 243-256). Z kolei Katarzyna Podniesińska omówiła krótką historię powstania kolekcji ekslibrisów bibliotek polskich, która znajduje się w zbiorach graficznych Muzeum Narodowego w Krakowie (Kolekcja ekslibrisów bibliotek polskich w zbiorach graficznych Muzeum Narodowego w Krakowie - wybrane problemy dotyczace prowe-

5 Magdalena LASKOWSKA, Witold Chomicz 1910-1984. Katalog wystawy dziel artysty ze zbiorów Ziyada Raoofa, Muzeum Narodowe w Krakowie, Kraków 2012.

Roczniki Biblioteczne 60, 2016

(C) for this edition by CNS 
niencji w latach 1900-1914, s. 337-346), a Anežka Šimková przybliżyła należące ongiś do praskiego historyka sztuki, bibliofila i marszanda Jana Poša, a dziś do Muzeum Sztuki w Ołomuńcu pełne uroku rękopiśmienne modlitewniki z lat 1750-1850, stanowiące unikatowy przykład tak zwanego baroku ludowego (Ręcznie pisane modlitewniki XVIII iXIX wieku jako fenomen kultury plastycznej Czech i Moraw. Zbiory bibliofilskie Muzeum Sztuki w Olomuńcu, s. 497-500). Z kolei Gina Renotière zaprezentowała znajdującą się również w Ołomuńcu, lecz tym razem w Muzeum Sztuki Nowoczesnej, kolekcję „Książka XX wieku" (s. 501-504).

Widać wyraźnie, iż spectrum zagadnień poruszanych w artykułach zgromadzonych w recenzowanym tomie jest bardzo szerokie, co dowodzi, że książka jest przedmiotem wielu niezwykle różnorodnych badań. Niewątpliwą zaletą tekstów jest uaktualnienie stanu badań nad książką, prowadzonych z perspektywy historyczno-artystycznej, oraz wskazanie kierunków, w jakich mogą podążać kolejne, dopiero planowane analizy. Dużym walorem recenzowanej pracy jest też staranność, z jaką została wydana. Opublikowany przez Collegium Columbinum w eleganckiej szacie graficznej tom $O$ miejsce książi w historii sztuki może być pod tym względem wzorem dla innych wydawnictw naukowych. Jedynym mankamentem jest tu jedynie format użytego w publikacji materiału ilustracyjnego. Śledzenie (dla przykładu) wnioskowania dotyczącego dekoracji piętnastowiecznych Godzinek na podstawie ilustracji wielkości znaczka pocztowego (s. 55-56) jest wielce kłopotliwe i pozostawia spory niedosyt. Dużą zaletą jest natomiast wyposażenie tomu w skorowidz nazwisk (opracowany przez Agnieszkę Gromek, s. 505523), który ułatwia odnajdywanie pożądanych informacji, a także zaopatrzenie każdego artykułu w anglojęzyczny abstrakt, czyniący całość dostępną również zagranicznym czytelnikom. Wszystko to sprawia, że $O$ miejsce ksiażki w historii sztuki można uznać nie tylko za lekturę cenną, lecz wręcz obowiązkową, zwłaszcza dla historyków sztuki i bibliologów.

Katarzyna Krzak-Weiss

Katalog inkunabutów Biblioteki Naukowej PAU i PAN w Krakowie. Oprac. Teresa Dąbrowa, Elżbieta Knapek, Jacek Wojtowicz, Polska Akademia Umiejętności. Biblioteka Naukowa Polskiej Akademii Umiejętności i Polskiej Akademii Nauk, Kraków: Polska Akademia Umiejętności 2015. 285, [1] s.: il., Bibliogr. s. 278-281. Indeks. Streszcz. ang. i niem. ISBN 978-83-7676-223-4

DOI: $10.19195 / 0080-3626.60 .20$

Od czasu wynalezienia przez Jana Gutenberga w połowie XV wieku sposobu odbijania tekstu za pomocą metalowej ruchomej czcionki pojawiają się w bibliotekach pierwsze książki drukowane, które określa się mianem inkunabułów. Dzisiaj te wytwory „,czarnej sztuki” należą do najcenniejszych obiektów w zbiorach każdej książnicy. Badacze od lat starają się zarejestrować i opisać wszystkie edycje, jakie ukazały się drukiem do roku 1500, a także odnotować wszystkie zachowane do dzisiaj egzempla- 